PENENTUAN NASABAH PENERIMA REWARD PRODUK GOLD DENGAN METODE SIMPLE ADDITIVE WEIGHTING (SAW) STUDI KASUS : PT. PINJAM INDONESIA

Riki Ruli A. Siregar; Faizal Fachrurrozi

IMPLEMENTASI METODE BACKWARD CHAINING PADA DATA WAREHOUSE DAOP 1 JAKARTA PT. KAI (PERSERO) Rakhmat Arianto; Chandra Bagus Sugiarto

IMPLEMENTASI METODE DETEKSI TEPI CANNY PADA OBJEK SEBAGAI MODEL KEAMANAN APLIKASI PADA SMARTPHONE ANDROID

Abdul Haris; Andi Prasetyo

ANALISA DATA DAN PERANCANGAN APLIKASI SERVICE PELANGGAN PT. JNE UNTUK PENINGKATAN KUALITAS LAYANAN

Dewi Arianti Wulandari; Sonny Syahrindra Putra

JARINGAN AD-HOC VEHICULAR (VANET) : TINJAUAN TENTANG ARSITEKTUR, KARAKTERISTIK, APLIKASI, DAN PROTOKOL MEDIUMACCESS CONTROL (MAC)

Rosida Nur Aziza

PERANCANGAN APLIKASI PENJADWALAN MATA KULIAH MENGGUNAKAN METODE CONSTRAINT PROGRAMMING Syam Gunawan

RANCANGAN TATA KELOLA PEREMAJAAN RUANG KELAS DIREKTORAT PEMBINAAN SEKOLAH DASAR

Ratna Mutu Manikam; Purwanto

PENGEMBANGAN AMORIK MENGGUNAKAN METODE GARIS SINGGUNG TERHADAP DUA LINGKARAN DAN PERSAMAAN KURVA BEZIER ORDE DUA.

Darma Rusjidi

OPTIMALISASI PENGAMBILAN KEPUTUSAN PENILAIAN KINERJA DOSEN PADA PERGURUAN TINGGI ISLAM XYZ MENGGUNAKAN AHP (ANALYTICAL HIERARCHY PROCESS)

Rahma Farah Ningrum

PENGAMANAN SMS PADA TELEPON SELULER BERBASIS ANDROID MENGGUNAKAN ALGORITMA TRIPLE DES Raka Yusuf; $M$. Rival Suheri

APLIKASI LATIHAN SOAL UJIAN TEORI SURAT IZIN MENGEMUDI BERBASIS WEB Harni Kusniyati; Raka Yusuf; Andri Setiawan

RANCANG BANGUN SIMULASI TERJADINYA LISTRIK DENGAN SUMBER DAYA SAMPAH BERBASIS MULTIMEDIA (STUDI KASUS : TPST BANTAR GEBANG)

Yasni Djamain; Ika Fitriyani Putri

\begin{tabular}{|c|c|c|c|c|c|c|}
\hline \multirow{2}{*}{ 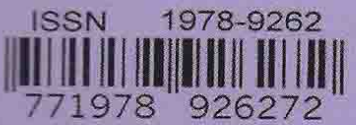 } & \multicolumn{6}{|c|}{ SEKOLAH TINGGI TEKNIK - PLN (STT-PLN) } \\
\hline & PETIR & VOL. 9 & NO. 1 & HAL. 1 - 87 & JAKARTA, MARET 2016 & ISSN $1978-9262$ \\
\hline
\end{tabular}




\title{
RANCANGAN TATA KELOLA PEREMAJAAN RUANG KELAS DIREKTORAT PEMBINAAN SEKOLAH DASAR
}

\author{
Ratna Mutu Manikam; Purwanto \\ Program Studi Sistem Informasi Fasilkom Universitas Mercu Buana \\ ratnamanikam@gmail.com; khesawasidhi@gmail.com
}

\begin{abstract}
Rejuvenation classroom is a reference to the Directorate of Primary School activity conducted on an ongoing basis. So the availability, truth and certainty of information from the renovation must show current conditions in order to meet the needs of the coaching process, accountability and financial audit, as well as in the management of data rejuvenation should be integrated in one unified database. Then it is necessary to build an application that is able to manage the process of rejuvenation consistently. In the design of the governance renewal application classrooms, use agile software development methodology with extreme approach to programming process to explain each activity in each phase of the design. Stages of design and implementation is limited to the aid management process module rejuvenation classroom consisting of the proposed input, input the data verification process, the process of filing the disbursement of funds, the process of managing the data returns, and the handling of school accountability reports. With the construction of this rejuvenation governance can help meet the needs of data and information quickly and accurately. So that the information presented can be used as one of the considerations in the process of planning, policy making, monitoring, evaluation and inspection.
\end{abstract}

Key word: design, rejuvenation, governance, information, classroom

\section{ABSTRAK}

Peremajaan ruang kelas merupakan acuan kegiatan Direktorat Pembinaan Sekolah Dasar yang dilaksanakan secara berkelanjutan. Sehingga ketersediaan, kebenaran dan kepastian informasi dari kegiatan peremajaan harus memperlihatkan kondisi terbaru agar memenuhi kebutuhan proses pembinaan, pertanggungjawaban dan audit keuangan, serta dalam pengelolaan data-data peremajaan harus terintegrasi dalam satu kesatuan database. Maka perlu dibangun aplikasi yang mampu mengelola proses peremajaan secara konsisten. Dalam perancangan aplikasi tata kelola peremajaan ruang kelas, digunakan metodologi agile software development dengan pendekatan extrem programming process untuk menjelaskan setiap kegiatan dalam setiap tahapan rancangan. Tahapan design dan implementasi dibatasi pada modul proses pengelolaan bantuan peremajaan ruang kelas yang tediri dari input usulan, proses input data verifikasi, proses pengajuan pencairan dana, proses pengelolaan data-data retur, dan penanganan laporan pertanggungjawaban sekolah. Dengan dibangunnya tata kelola peremajaan ini dapat membantu memenuhi kebutuhan data-data dan informasi secara cepat dan akurat. Sehingga informasi yang sajikan dapat dijadikan sebagai salah satu pertimbangan dalam proses perencanaan, pengambilan kebijakan, monitoring, evaluasi dan pemeriksaan.

Kata kunci : rancangan, peremajaan, tata kelola, informasi, ruang kelas

\section{Pendahuluan}

\subsection{Latar Belakang}

Setiap satuan pendidikan menyelenggarakan proses belajar mengajar menggunakan ruang kelas untuk memfasilitasi interaksi antara peserta didik dan pendidik. Proses belajar mengajar dalam ruang kelas akan berjalan dengan baik apabila didukung oleh kondisi ruang yang memadai. Ruang kelas dalam lingkup pendidikan formal disebut memadai apabila memenuhi standar minimum sarana prasarana baik aspek luas, tata bangunan, keselamatan, kesehatan dan kenyamanan sebagaimana tertuang dalam Lampiran Peraturan Menteri Pendidikan Nomor 24 Tahun 2007.

Pada tahap perencanaan dan penganggaran Direktorat Pembinaan Sekolah Dasar melakukan analisa kebutuhan dengan memperhitungkan jumlah sasaran ruang kelas dan secara proporsional menetapkan quota ruang kelas sesuai alokasi anggaran kementerian untuk output rehabilitasi, kemudian diinformasikan ke Dinas Pendidikan Kabupaten/Kota. Permasalahan mendasar pada saat proses perencanaan adalah belum adanya jaminan ketersediaan data riil kondisi ruang kelas yang dapat digunakan sebagai bahan referensi perencanaan rehabilitasi secara makro sehingga sebagai alternatif digunakan daftar usulan sekolah sebagai dasar perencanaan awal. Sementara jumlah lembaga/sekolah yang mengusulkan bantuan rehabilitasi ke Direktorat Pembinaan Sekolah Dasar sangat banyak dengan berbagai macam format. 


\subsection{Rumusan masalah}

Berdasarkan latar belakang yang telah diuraikan di atas maka dirumuskan masalahmasalah sebagai berikut :

1. Bagaimana membangun sistem administrasi yang dapat menjamin konsistensi numenklatur usulan sekolah dan terhindar dari duplikasi?

2. Bagaimana formulasi pembiayaan rehabilasi ruang kelas masing-masing kabupaten/kota dapat diterapkan secara efektif dalam sistem aplikasi?

3. Bagaimana pencatatan dokumen-dokumen yang berkorelasi dengan proses penyelenggaraan rehabilitasi dilakukan secara efektif dan efisien, sehingga mempermudah dalam proses penelusuran, pelaporan, dan pertanggung jawaban?

4. Bagaimana perekaman data-data pengelolaan bantuan rehabilitasi secara simultan dari tahun ke tahun, sehingga Direktorat Pembinaan Sekolah Dasar dapat dengan cepat melayani permintaan laporanlaporan yang berhubungan dengan bantuan rehabilitasi, sekaligus melepaskan ketergantungan data-data pengelolaan rehabilitasi dari sifat personal ke lembaga?

\subsection{Batasan Masalah}

Berdasarkan rumusan masalah yang telah diuraikan di atas dan kerangka pembahasan selanjutnya tetap dalam ruang lingkup permasalahan yang terarah, maka perlu dilakukan pembatasan masalah. Batasan-batasan masalah yang tidak di bahas dalam penelitian ini adalah sebagai berikut:

1. Mekanisme perencanaan, penetapan quota dan penentuan alokasi anggaran yang didistribusikan ke Dinas Pendidikan Kabupaten/Kota sebagai dasar pelaksanaan seleksi dan verifikasi.

2. Mekanisme pencairan rehabilitasi ruang kelas yang dilakukan oleh Satuan Kerja Direktorat Pembinaan Sekolah Dasar sebagai lembaga penerbit Surat Perintah Membayar (SPM), Kantor Pusat Perbendaharaan Negara (KPPN) sebagai penerbit Surat Perintah Penyaluran Dana (SP2D) dan Bank Penyalur sebagai lembaga yang memiliki otoritas penyaluran dana langsung ke rekening sekolah.

3. Mekanisme pemberitahuan yang dapat memberikan jawaban komprehensif terhadap pertanyaan seputar penyelenggaraan rehabilitasi ruang kelas oleh sekolah yang mengusulkan dan tidak lolos atau tidak diverifikasi oleh Dinas Kabupaten/Kota.

4. Mekanisme penyampaian informasi tentang kepastian kapan dana masuk ke rekenenig sekolah setelah penerbitan Surat Perintah Membayar (SPM) oleh Satuan Kerja Direktorat Pembinaan Sekolah Dasar dan SP2D oleh KPPN Jakarta III.

\subsection{Tujuan}

Tujuan penelitian adalah membangun aplikasi tata kelola peremajaan ruang kelas sekolah dasar di lingkungan Direktorat Pembinaan Sekolah Dasar untuk membantu proses pengendalian internal pelaksanaan peremajaan bagi pengelola kegiatan.

2. Tinjauan Pustaka

2.1 Pengertian Bantuan Sosial Bidang Pendidikan

Bantuan sosial di bidang pendidikan adalah pengeluaran berupa transfer uang, barang atau jasa yang diberikan kepada masyarakat guna melindungi masyarakat dari kemungkinan terjadinya risiko sosial, meningkatkan kemampuan ekonomi dan/atau kesejahteraan masyarakat di bidang pendidikan dan kebudayaan. Risiko Sosial di bidang pendidikan dan kebudayaan yang selanjutnya disebut risiko sosial adalah kejadian atau peristiwa yang dapat menimbulkan potensi terjadinya kerentanan sosial yang ditanggung oleh individu, keluarga, kelompok dan/atau masyarakat sebagai dampak krisis sosial, krisis ekonomi, krisis politik, fenomena alam, dan bencana alam yang jika tidak diberikan belanja bantuan sosial akan semakin terpuruk dan tidak dapat hidup dalam kondisi wajar di bidang pendidikan dan kebudayaaan (Kemdikbud, 2013).

\subsection{Pengertian Rehabilitasi Ruang Kelas Rusak}

Sebagaimana tertuang dalam Petunjuk Teknis Pelaksanaan Rehabilitasi Ruang Kelas Sekolah Dasar Tahun 2014, yang dimaksud dengan rehabilitasi ruang kelas rusak adalah memperbaiki ruang kelas yang telah rusak sebagian dengan maksud menggunakan sesuai dengan fungsi tertentu yang tetap, baik arsitektur maupun struktur bangunan tetap dipertahankan seperti semula, sedang utilitas dapat berubah dengan kategori sebagai berikut:

1. ruang kelas rusak ringan apabila kerusakan pada sebagian komponen non struktural dan atau komponen struktural dengan tingkat kerusakan lebih dari $0 \%$ sampai dengan $30 \%$.

2. ruang kelas rusak sedang apabila kerusakan pada sebagian komponen non struktural dan atau komponen struktural dengan tingkat kerusakan lebih dari $30 \%$ sampai dengan $45 \%$.

3. ruang kelas rusak berat apabila kerusakan pada sebagian komponen non struktural dan atau komponen struktural dengan tingkat kerusakan lebih dari $45 \%$ sampai dengan $65 \%$.

4. ruang kelas rusak total apabila kerusakan pada sebagian komponen non struktural dan atau komponen struktural dengan tingkat kerusakan lebih dari $65 \%$.

\subsection{Pengembangan Perangkat Lunak dengan Model Pendekatan Extrem Programming (XP) Process.}

Extrem Programming merupakan salah satu model pengembangan sistem dari metodologi Agile Development yang diharapkan mampu memenuhi 
beragam perubahan pengembangan sistem yang disebabkan karena kesulitan memprediksi kebutuhan perangkat lunak yang disebabkan karena perkembangan berbagai aspek kebutuhan user, analisa, perancangan dan konstruksi yang tidak bisa diprediksidari sudut pandang perencanaan.

Pressman (2010) dalam bukunya mengemukakan bahwa extrem programming menggunakan pendekatan berorientasi objek dalam paradigma pengembangan sistem yang mencakup seperangkat aturan dan praktik yang terjadi dalam kontek empat kegiatan pokok (framework) yang meliputi perencanaan, desain, coding dan testing.

\section{Metodologi Penelitian}

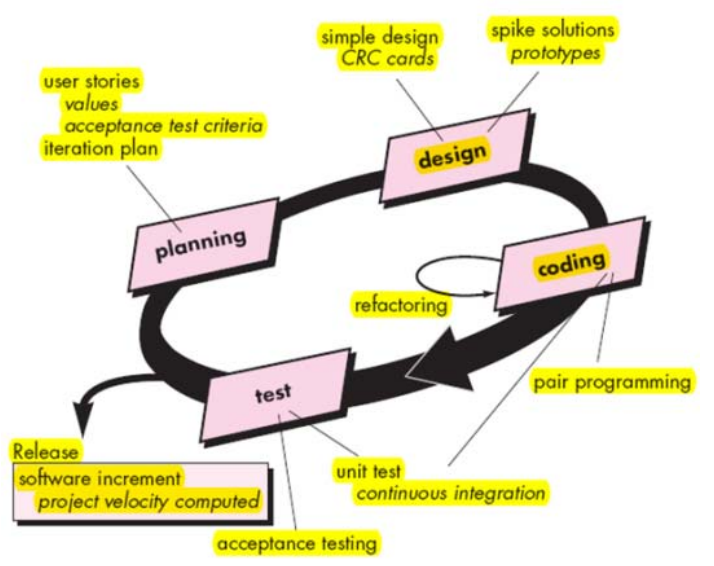

Gambar 1. The Extrem Programming Process

(Pressman, 2010)

Dalam bukunya Pressman menjelaskan empat framework dalam model extrem programming process sebagai berikut:

1. Tahap Planning

Tahap planning dalam berfokus terhadap bagaimana mendapatkan gambaran fungsional dan fitur dari sistem yang akan dibangun, diawali dengan membuat semacam user stories yang berisi indek gambaran yang diberikan oleh user dan ditentukan berdasarkan prioritas-prioritas pekerjaan yang harus dilakukan.

2. Tahap Design

Aktifitas design berlangsung secara terus menerus selama pengembangan aplikasi berlangsung yang bertujuan untuk mengatur pola logika dalam sistem yang sedang dibangun. Penciptaan purwarupa rancangan dimungkinkan jika ditemukan masalah desain yang rumit dengan tujuan untuk meminimalisir resiko kegagalan.

3. Tahap Coding

Setelah menyelesaikan design untuk aplikasi secara keseluruhan, modul unit tes dibuat terlebih dahulu sebelum melakukan implementasi kode program. Hal ini bertujuan untuk melakukan uji coba setiap gambaran yang didapat dari user. Setelah berbagai unit tes selesai dibangun, barulah melanjutkan aktivitasnya ke penulisan coding aplikasi.

4. Tahap Testing

Pengujian pada model extrem programming sudah dilakukan juga pada saat tahapan sebelum coding. Extrem programming menerapkan perbaikan terhadap sekecil apaun masalah yang terjadi dengan konsep lebih cepat lebih baik dibandingkan menyelesaikan masalah pada saat akhir. Oleh karena itu, setiap modul yang sedang dikembangkan akan terlebih dahulu mengalami pengujian denga modul unit tes yang telah dibuat sebelumnya.

Setelah semua modul telah dikumpulkan dalam sebuah sistem yang sempurna, barulah pengujian penerimaan (acceptance test) dilakukan. Pada tahapan pengujian ini aplikasi langsung diuji coba oleh pengguna dan untuk mendapat tanggapan langsung.

Extreme Programming adalah metodologi yang unik yang mewujudkan prinsip-prinsip agile. Elemen utama dari XP adalah bahwa tes sistem ditulis terlebih dahulu dan para programmer bekerja berpasangan untuk merancang, menuliskan kode program dan melakukan uji program. Sehingga ketika sebuah fungsi (dari program) selesai dikerjakan tidak hanya hanya di rancang dan dituliskan kode programnya tetapi sekaligus telah ditinjau dan diuji. Hal ini sebagaimana dijelaskan oleh Satzinger et al. (2010) sebagai berikut:

Extreme Programming are unique methodologies that embody agile principles. Core elements of XP are that the system tests are written first and that programmers work in pairs to design, code, and test the software. So, when a function is completed, it has not only been designed and coded, but it has also been reviewed and tested.

\section{Hasil dan Analis}

\subsection{Use Case Diagram Sistem Berjalan}

Dari rincian tugas setiap kelompok kerja (Pokja), uraian prosedur dan ricth picture mekanisme pemberian bantuan rehabilasi ruang kelas di atas dapat digambarkan sistem yang sedang berjalan dengan menggunakan use case diagram sebagai berikut: 


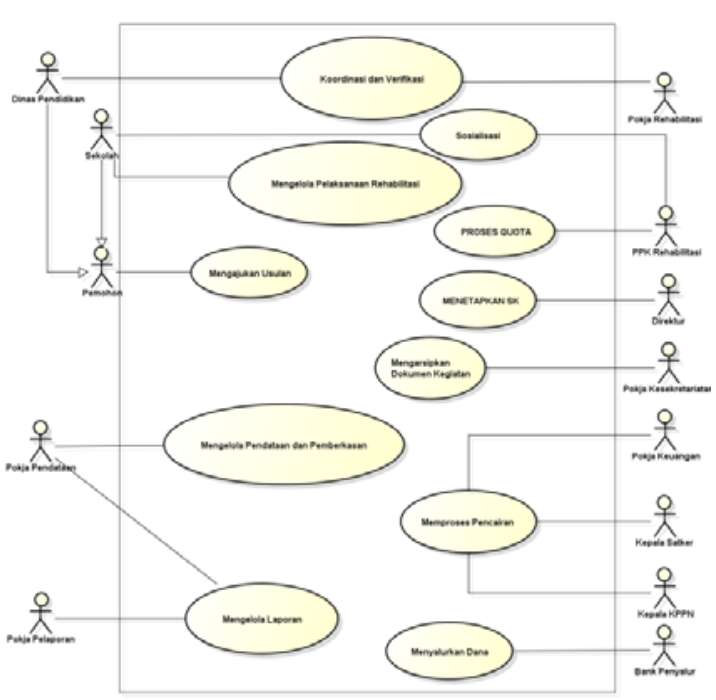

Gambar 2. Use Case Bantuan Rehabilitasi Ruang Kelas Pada Sistem Berjalan

Berdasarkan analisa use case sistem berjalan terdapat proses dapat diketahui bahwa masih banyak proses administrasi tidak sistematis. Terutama pada pekerjaan-pekerjaan yang menyangkut perekaman data, penyimpanan data dan pengolahan data-data rehabilitasi yang tidak melekat pada lembaga dalam bingkai sebuah sistem yang efektif, tetapi melekat pada pegawai secara personal. Kondisi kebergantungan kepada personal secara langsung maupun tidak langsung akan mempengaruhi kinerja sistem Direktorat pada umumnya.

\subsection{Perancangan Aplikasi}

Pengelolaan administrasi rehabilitasi ruang kelas di Direktorat Pembinaan Sekolah Dasar tidak lepas dari tata kelola berkas yang harus ditata sedemikian rupa. Sehingga perancangan aplikasi rehabilitasi yang dilakukan diharapkan dapat membantu mempercepat proses administrasi berkas yang tidak bersifat fisik, tetapi berhubungan erat dengan dokumen-dokumen fisik rehabilitasi. Tata kelola dokumen non fisik seperti pengelolaan data-data data usulan sekolah, data hasil verifikasi, data pengajuan pencairan, pencatatan SPM, SP2D, Surat Pemberitahuan Retur, Surat Pernyataan Dana Belum Masuk, Surat Pemberitahuan Dana Masuk, pencatatan laporan sekolah, Rekapitulasi/Laporan Usulan, Laporan Realisasi per tahun, Laporan Retur harus dirancang dengan baik untuk mempercepat dan mempermudah proses pernyiapan dan pencatatan dokumen-dokumen rehabilitasi tersebut.

\section{Usulan Rancangan Sistem Sistem Aplikasi Pengelolaan Rehabilitasi Ruang Kelas Sekolah Dasar}

Tahap perancangan aplikasi untuk membangun suatu aplikasi dengan mengkonfigurasikan komponen-komponen perangkat lunak dan perangkat keras sehingga menghasilkan sistem aplikasi yang baik. Pemodelan aplikasi diusahakan mendekati sama realitas yang terjadi dalam proses bantuan rehabilitasi. Dengan menggunakan diagram-diagram UML penggambaran rancangan ini diharapkan dapat dipahami dengan mudah sehingga pada tahap implementasi tidak ada kesulitan.

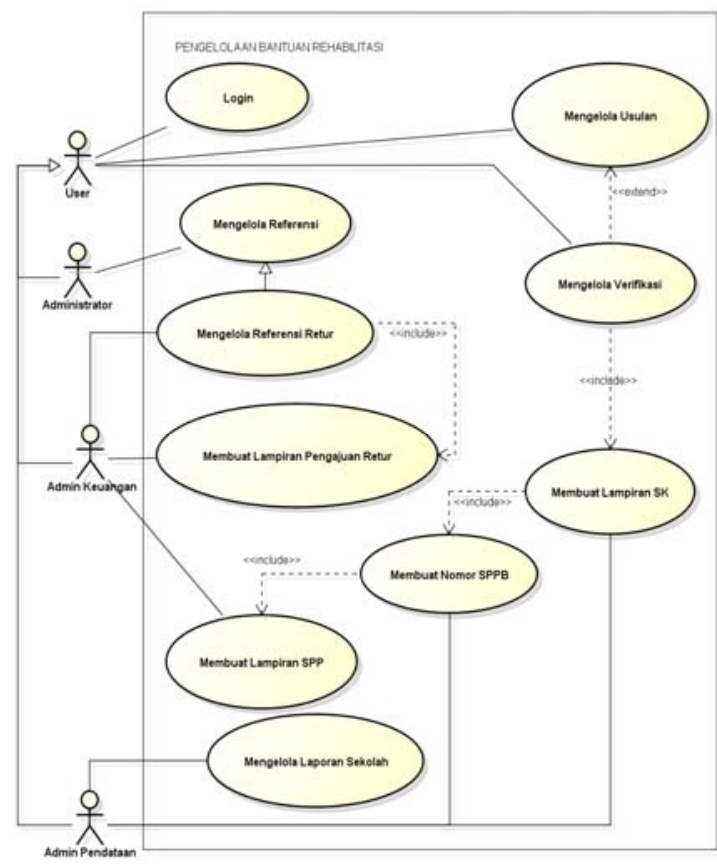

Gambar 3. Usecase Diagram Sistem Aplikasi Usulan

\subsection{Perancangan Antarmuka}

Analisis perancangan antarmuka (interface) dalam sistem aplikasi pengelolaan bantuan rehab ini meliputi: perancangan struktur menu utama, perancangan frame-frame input, perancangan keluaran. Perancangan antarmuka dimaksudkan agar mendapatkan gambaran jelas tentang bagaimana tampilan aplikasi, sehingga pada saat implementasi dalam tahap pemrograman dapat dilakukan dengan efektif.

\section{a. Perancangan Form Referensi Sekolah}

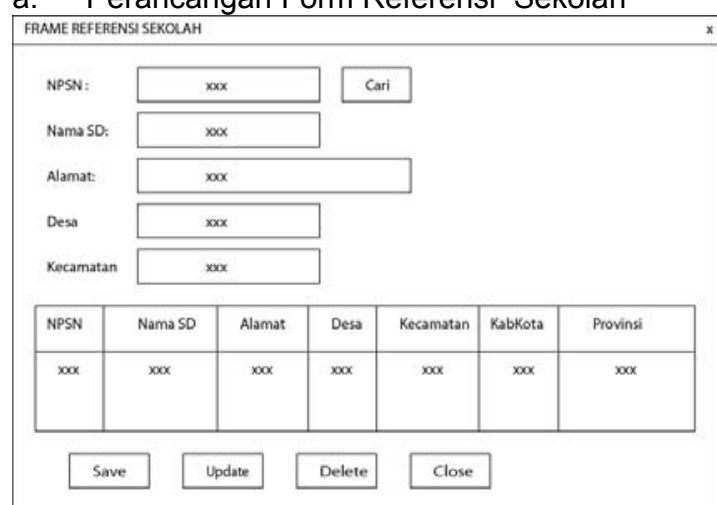

Gambar 4. Rancangan Frame Referensi Sekolah 
b. Dialog Pencarian Sekolah

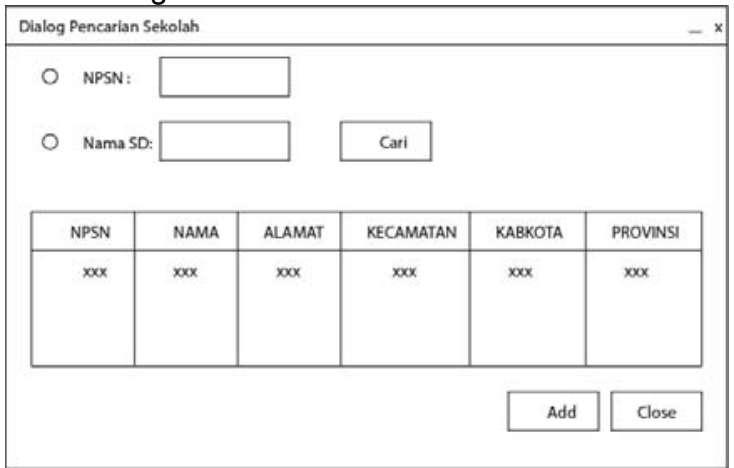

Gambar 5. Rancangan Dialog Pencarian Referensi Sekolah

C. Form Referensi Tahun Biaya

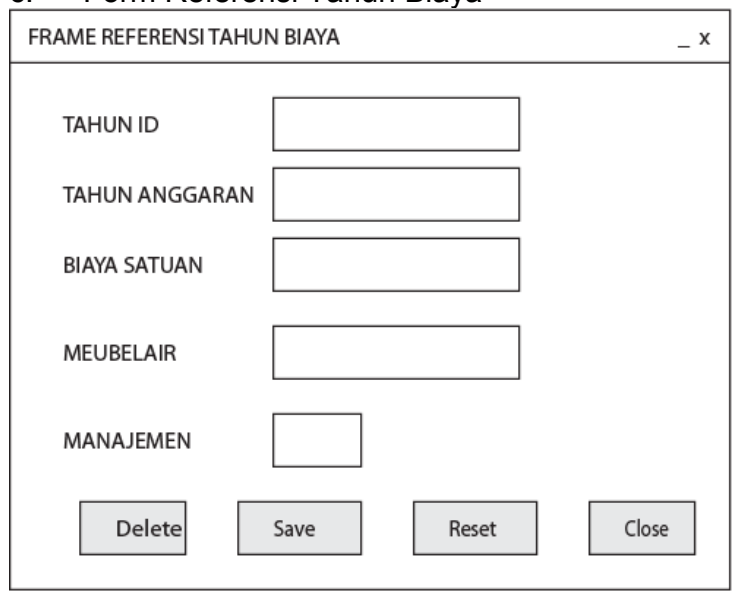

Gambar 6. Rancangan Frame Referensi Tahun Satuan Biaya

d. Perancangan Frame Administrasi Usulan

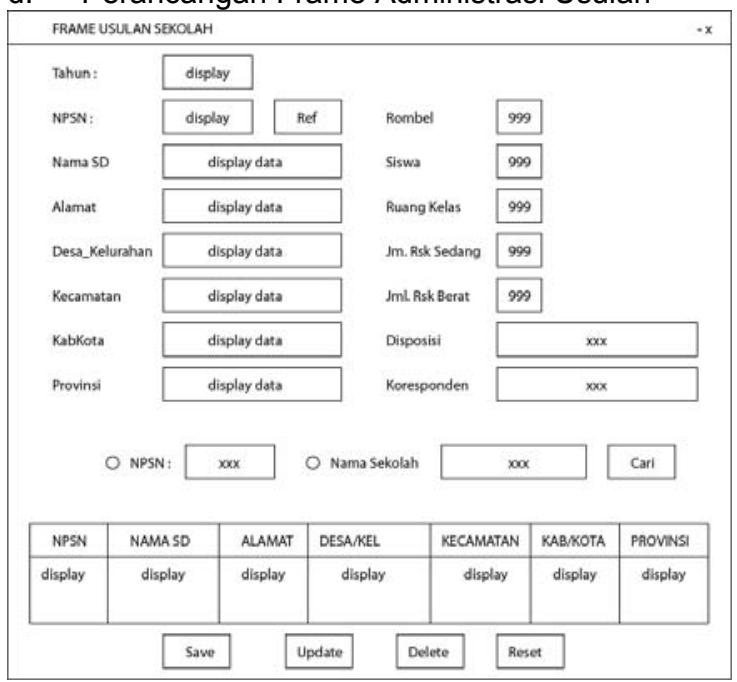

Gambar 7. Rancangan Frame Usulan Bantuan e. Dialog Pencarian Sekolah Usulan

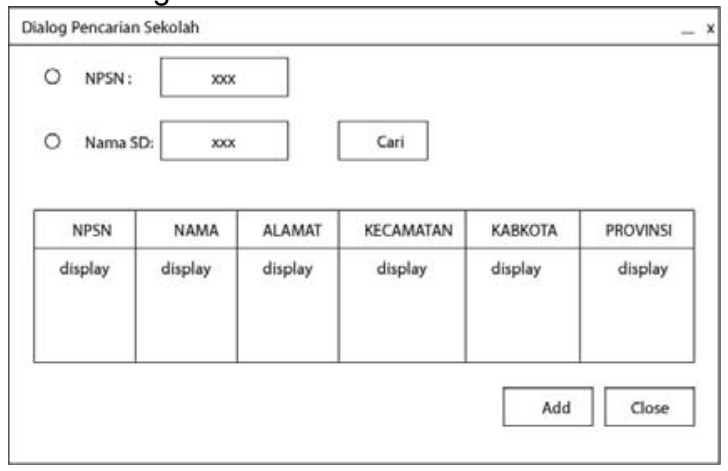

Gambar 8. Rancangan Dialog Pencarian Usulan

f. Rancangan Output Rekapitulasi Usulan Per Provinsi

DIREKTORAT PEMBINAAN SEKOLAH DASAR DAFTAR USULAN REHABILTASI RUANG KELAS

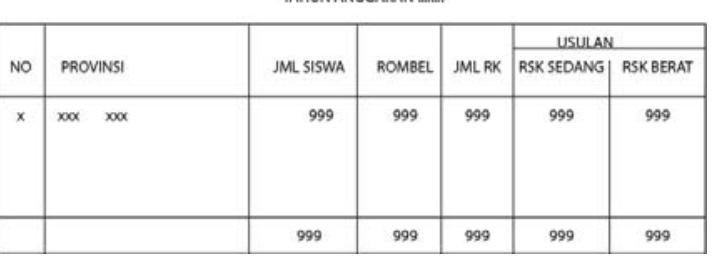

Gambar 9. Rancangan Laporan Usulan Per Provinsi

g. Racangan Rekapitulasi Usulan Per Kabupaten/Kota

DIREKTORAT PEMBINAAN SEKOLAH DASAP

DAFTAR USULAN REHABILTASI RUANG KELLS PER KABUPATEN/KOTA

\begin{tabular}{|c|c|c|c|c|c|c|}
\hline \multirow[b]{2}{*}{ No } & \multirow[b]{2}{*}{ KABUPATEN/KOTA } & \multirow[b]{2}{*}{ JML SISWA } & \multirow[b]{2}{*}{ ROMBEL } & \multirow[b]{2}{*}{ JML RK } & \multicolumn{2}{|l|}{ USULAN } \\
\hline & & & & & RSK SEDANG & RSK BERAT \\
\hline$x$ & $x \operatorname{xoc}$ & 999 & 999 & 999 & 999 & 999 \\
\hline & & 999 & 999 & 999 & 999 & 999 \\
\hline
\end{tabular}

Gambar 10. Rancangan Laporan Usulan Per Kabupaten/Kota

\section{Kesimpulan}

Setelah semua tahap pembahasan dalam rangka pembuatan sistem administrasi pengelolaan bantuan rehabilitasi ruang kelas ini dilakukan, mulai dari pembuatan proposal, kajian teori, analisa sistem berjalan dan analisa perancangan aplikasi, sampai dengan tahapan implementasi dan pengujian, dapat disimpulkan bahwa:

1. Rancangan ini mengakses database tunggal dengan menggunakan nomor statistik pendidikan nasional (NPSN) sebagai identitas sekolah yang secara mutlak melekat pada sekolah sehingga dapat menghindari ketidakkonsistenan data individu sekolah pada tahapan usulan rehabilitasi.

2. Perhitungan pembiayaan dilakukan dengan menggunakan aplikasi yang mengakses pada 
database referensi indek kemahalan konstruksi tiap kabupaten sehingga menghindari kesalahan perhitungan pembiayaan rehabilitasi per sekolah,

3. Pencatatan dokumen-dokumen yang berkaitan langsung dengan penyelenggaran rehabilitasi ruang kelas di Direktorat Pembinaan Sekolah Dasar dapat dilakukan secara efektif.

4. Data-data pelaksanaan rehabilitasi ruang kelas disimpan dalam satu kesatuan database yang terintegrasi dengan data referensi dalam server Direktorat Pembinaan Sekolah Dasar, sehingga dalam kondisi normal menghindari kehilangan data dan melepaskan ketergantungan data pada personal pegawai dari tahun ke tahun.

\section{Daftar Pustaka}

Dennis, A., Wixom, B. H., \& Roth, R. M. (2012). System Analysis and Design. United States of America: John Wiley \& Sons, Inc.

Fathansyah. (2012). Basis Data. Bandung: Informatika.

Guritno, S., Sudaryono, \& Rahardja, U. (2011). Theory adn Application of IT Research Metodologi Penelitian Teknologi Informasi. Yogyakarta: Andi Offset.

Heriyanto, I., \& Raharjo, B. (2009). Menguasai Oracle, SQL dan PL/SQL Metode Praktis Mempelajari Pemrograman Oracle. Bandung: Informatika.

Herlawati, P. P. (2011). Menggunakan UML. Bandung: Informatika Bandung.

Kemdikbud. (2010). Rencana Strategis (Renstra) Kementerian Pendidikan Nasional tahun 2010--2014. Jakarta: Kementerian Pendidikan Nasional.

Mulyanto, A. (2009). Sistem Informasi Konsep dan Aplikasi. Yogyakarta: Pustaka Pelajar.

Presman, R. S. (2012). Rekayasa Perangkat Lunak (Pendekatan Praktisi Edisi 7). Yogyakarta: 2012.

Satzinger, W. J., Jackson, B. R., \& Burd, D. S. (2010). Systems Analysis and Design in a Changing World. Canada: Course Technology.

Siahaan, D. (2012). Analisa Kebutuhan dalam Rekayasa Perangkat Lunak. Yogyakarta: Andi Offset.

Simarmata, J. (2009). Perancangan Basis Data. Yogyakarta: Andi Offset.

Sutejo, S.Kom, B., \& Michael AN, S.Kom. (2010). Algoritma dan Teknis Pemrograman Konsep, Implementasi dan Aplikasi. Yogyakarta: Andi Offset.

Tata Sutabri. (2012). Analisa Sistem Informasi. Jakarta: Andi Offset.

Wahyudi, B. (2008). Konsep Sistem Informasi dari BIT sampai ke Database. Yogyakarta: Andi Offset.
Yasin, V. (2012). Rekayasa Perangkat Lunak Berorientasi Objek Pemodelan Arsitektur dan Perancangan (Modeling, Architecture and Design). Jakarta: Mitra Wacana Media.

(2013). Peraturan Menteri Pendidikan dan Kebudayan Nomor 24 Tahun 2013 tentang Pedoman Umum Pengelolaan dan Pertanggungjawaban Belanja Bantuan Sosial di lingkungan Kementerian Pendidikan dan Kebudayaan. Jakarta: Kementerian Pendidikan dan Kebudayaan. (2014). Petunjuk Teknis Pelaksanaan Rehabilitasi Ruang Kelas Sekolah Dasar. Jakarta. 